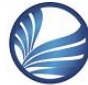

ELK

Asia Pacific Journals

WWw.elkjournals.com

\title{
ROLE OF EMPLOYEE WELFARE FACILITIES ON ORGANIZATIONAL BRANDING AMONG THE EMPLOYEES - WITH SPECIAL REFERENCE TO SYNTHITE INDUSTRIES LIMITED, HARIHAR
}

\begin{tabular}{|c|c|}
\hline * DR. J.K. RAJU B.E., MBA, Ph.D. & $* *$ MR. NAVEEN G. NAIK. BE, MBA. \\
Associate Professor, Institute of Management & Faculty, Bapuji Institute of Engineering and \\
Studies, Shivagangotri, Davangere University, & Technology (BIET) MBA Programme, \\
Davangere, Karnataka, & Bapuji B-Schools, Davangere, Karnataka, \\
India - 577 004 & India - 577 004 Email ID: navingnaik@gmail.com \\
& (Corresponding Author) \\
\hline
\end{tabular}

\begin{abstract}
This paper attempts to understand the relationship between employee welfare facilities \& organizational branding, and how it helps to build a positive image in the minds of the employees of the organization. The study has been conducted at "SYNTHITE INDUSTRIES LIMITED, Harihar". For the study, a detailed personal interview was conducted using structured questionnaire to collect primary data. The secondary data was collected through websites, text books. Sample size of 50 respondents was chosen on the basis of random sampling. The main objective of study the welfare facilities provided at Synthite Industries Ltd., Paper deals with the detailed study of the organisation. It contains a detail research design including problem area, objectives of the study, scope of the study. The data analysis is done on the response of the sample, inference are drawn based on the analysis of the data. The study also includes suggestions which can be taken into consideration to increase the efficiency of the workers. This study was an exposure to a working environment and clarified many things related to Employee Welfare Measures. So the whole study comprehends the employee welfare facilities at Synthite Industries Ltd., Harihar.
\end{abstract}

Key words: Employee Welfare Facilities, Employees, Organizational Branding, Random Sampling.

\section{Introduction}

Employee or labour welfare is an inclusive term of various services, benefits and facilities offered to employees by the employers. Or the effort to make life worth living for workmen. In order to retain and maintain to serve the organisation better the employees have to be trained and compensated through various fringe benefits the employer makes the life worth living for employees, the welfare facilities are extended its normal and economic rewards available to employees as per the legal provisions. 


\section{ELK ASIA PACIFIC JOURNAL OF HUMAN RESOURCE MANAGEMENT AND ORGANISATIONAL BEHAVIOUR}

ISSN 2394-0409; DOI: 10.16962/EAPJHRMOB/issn.2394-0409; Volume 2 Issue 1 (2015)

"Labour welfare which improves the health, safety and general well-being of the industrial efficacy of the workers beyond the minimum standard laid down by the legislation."

The Government trade unions and non-government agencies in addition to employer may also provide welfare measures. The basic purpose of labour welfare is to enrich the life of employees and then keep them happy and work effectively. Welfare measures to extend certain benefits to employees in addition to wages. Voluntary benefits are the results of employers generosity enlighten and philanthropic feelings.

The term "labour welfare" is very inclusive term which includes various types of activities under taken for the economic, social, Intellectual or moral benefit of the labour community. The term welfare is applied to the industrial workers one which must necessarily be elastic, bearing a somewhat different interpretation in one country from another, according to the education development of the worker.

There are some who emphasis voluntary nature of welfare work and include only that work in labour welfare which is undertaken by an employer "to establish, with in the existing industrial system, working and sometimes living and natural conditions of his employees beyond what is required by law, the customs of industry and conditions of the market" and there are who define labour welfare as "measures for promoting physical and general wellbeing of people working in factories and other undertakings of industrial life."

The fact of matter is that "welfare services are as life itself and are constantly being adopted to new circumstances. They form a fluid and developing pattern, which changes as human needs change, as problem of adjustment on social environment arise or with the changes which are perpetually going on in the structure of society itself. It is on wonder, therefore, that concept of industrial welfare vary from country to country and that within same country the significance attached to the term may differ from industry and even from undertaking."

Welfare means progressing or doing well. It is a comprehensive term, and refers to the physical, mental, moral and emotional wellbeing of individual. The concept of "employee welfare" is flexible and elastic and differs widely with time, region, industry, social values 


\section{ELK ASIA PACIFIC JOURNAL OF HUMAN RESOURCE MANAGEMENT AND ORGANISATIONAL BEHAVIOUR}

ISSN 2394-0409; DOI: 10.16962/EAPJHRMOB/issn.2394-0409; Volume 2 Issue 1 (2015)

and customs, degree of industrialization, to generic socio-economic development of the people and the political ideologies prevailing at a particular time. It is moulded according to the age, sex, socio cultural background, martial and economic status and education levels of the workers in various industries.

Labour investigation committee "such services facilities and amenities as may be established in or in the vicinity of undertakings to enable the persons employed in them to perform their work in healthy, congenial surroundings and provide with amenities conductive to good health and high moral." "such services facilities and amenities as adequate canteens, rest and recreation facilities sanitary and medical benefits, argument for travel to and place of work, and for accommodation of workers employed at a distance from their homes and such other services, amenities and facilities, including security measures as contribute to the conditions under which workers are employed

\subsection{Organization Branding}

"Branding" by definition is the coherent outward expression projected by an organization. A "corporate brand" is a product of an organization's corporate strategy, mission, image, and activities. Corporate brands distinguish organizations from their competitors, orient the organization in the minds of customers and employees, and create a perception of what an organization stands for.

“Organizational branding" refers to the practice of promoting the brand name of a corporate entity, as opposed to specific products or services. The activities and thinking that go into corporate branding are different from product and service branding because the scope of a corporate brand is typically much broader. It should also be noted that while corporate branding is a distinct activity from product or service branding, these different forms of branding can, and often do, take place side-by-side within a given corporation. The ways in which corporate brands and other brands interact is known as the corporate brand architecture.

Employer Branding is a concept evolved from the light of consumer branding. A strong consumer brand brings profit to the companies and influences the growth of it. A strong employer brand has a positive influence on the business as a whole. (Dell \& Ainspan 2001), points out organizations 


\section{ELK ASIA PACIFIC JOURNAL OF HUMAN RESOURCE MANAGEMENT AND ORGANISATIONAL BEHAVIOUR}

ISSN 2394-0409; DOI: 10.16962/EAPJHRMOB/issn.2394-0409; Volume 2 Issue 1 (2015)

have found that effective employer branding leads to competitive advantage which helps employees to adopt company values and beliefs and assists in employee retention. According to Singh M. K and Sonal Sharma (2013), effective employer branding leads to attracting and recruiting talented employees, increase in the retention rates and a higher level of organization commitment.

The term "employer brand" signifies what kind of employees currently working with an organization, employer branding has been defined as a company's efforts to communicate to existing and new staff what makes it an attractive place to work and maintaining a company's image in the eyes of its associates and potential hires (Nupur Bhati, 2014). Employer branding is therefore concerned with the attraction, engagement and retention initiatives targeted at enhancing the company's employer brand. Employer branding has recently become a very prevalent concept for HR professionals and researchers.

Nowadays, organizations have become aware that through the practice of Employer Branding the best talent in the market can be attracted, retained, and motivated. Earlier, organizations used to attract the talent by offering good compensation packages, but gradually, it has been observed that it is not only good salary that attracts the employees; but other factors too influence the choice of organization by the employees. Employer branding is a relatively new approach towards recruiting and retaining the best possible human talent within an employment environment that is becoming increasingly competitive (Backhaus and Tikoo, 2004). The term Employer Brand was first used in the early 1990s to signify an organizations reputation as an employer (Barrow and Mosley, 2005). Since then, it has been commonly implemented by the global management community. Employer brand is the image of an organization as a great place to work in the mind of current employees and key stakeholders in the external market (active and passive candidates, clients, customers, and other key stakeholders). The art and science of employer branding is, therefore, concerned with the attraction, engagement, and retention of initiatives targeted at enhancing a company's employer brand (Minchington, 2010).

In our world people react more and more to names and reputations, to 


\section{ELK ASIA PACIFIC JOURNAL OF HUMAN RESOURCE MANAGEMENT AND ORGANISATIONAL BEHAVIOUR}

ISSN 2394-0409; DOI: 10.16962/EAPJHRMOB/issn.2394-0409; Volume 2 Issue 1 (2015)

rumours and word of mouth. They do not see the headquarters or the factories any more (Kapferer J-N., 2008).In a survey of 703 people, $61 \%$ said they had found their most recent job via word-of-mouth (Cassidy C. And Kreitner R., 2010). Organization's employees will talk to their friends and family about their job. They are quite likely to encourage them to apply for an opening if they feel good about the organization, their supervisors, and the nature of their job.

Brennan, Locke and Naidoo (2007) claimed that UK academic staff are mostly employed as fixed-term contract staff; and therefore, they tend to leave when their contract ends to find a permanent job or to pursue a better job opportunities in academia. The findings of Metcalf et al. (2005) suggest that providing reasonable pay and promotion opportunities will reduce staff turnover for universities. Promotion was found to highly influence retention of academic staff (Brennan, Locke \&Naidoo 2007; Locke 2007; Metcalf et al. 2005). Likewise this study will help to find out many other factors will influence the employees to stay back with the organization for a longer duration and serve better.

\subsection{Industry Profile And Company Profile}

Food processing sector is vital for the overall development of economy as it provides a vital linkage and synergy between the agriculture and industry. It helps to diversify and commercialize farming; enhance income of farmers; create markets for export of agro foods as well as generate great employment opportunities. Through the presence of such industries, a wider range of food products could be sold and distributed to the distant locations. Food processing industry is one of the largest industry in India and is ranked $5^{\text {th }}$ in terms of production, consumption and export. Earlier, food processing was largely confined to the food preservation, packing and transportation, which mainly involved salting, curdling, drying, pickling....etc. However, over the years, with emerging new markets and technologies, the sector has widened its scope

The Indian food processing industry stands at $\$ 135$ billion and is estimated to grow with a CAGR of 10 per cent to reach $\$ 200$ billion by 2015 . The food processing industry contributed $7 \%$ to India's GDP. The industry employs around 13 million workers directly and 


\section{ELK ASIA PACIFIC JOURNAL OF HUMAN RESOURCE MANAGEMENT AND \\ ORGANISATIONAL BEHAVIOUR}

ISSN 2394-0409; DOI: 10.16962/EAPJHRMOB/issn.2394-0409; Volume 2 Issue 1 (2015)

about 35 million indirectly. The industry is segmented into sectors namely milk, and allied products (diary), meat and poultry, seafood, baker and confectionery, fruit and vegetables, grain, pulses and oilseeds (staple) products, alcoholic and non-alcoholic products (beverages), and packaged foods. The classification is not distinct as many processed products overlap different segments.

\subsubsection{Synthite Industrial Chemicals}

\section{Limited, Harihar}

Synthite Industrial Chemicals Limited, Harihar Division commenced its operations in 2001 and with a short span of time, developed into a major exporter, covering chilly Oleoresins, essential accredited for ISO 9001:2008 and ISO 2000-2005 from BSI, UK. The quality control laboratory equipped with the most modern analytical instrumentations closely monitors and controls product quality to meet exact customers' requirements. The products are HALAL, Kosher certified and Passover certificate.

Synthite Industries Ltd., Harihar has implemented "Integrated Management System" comprising Quality and food safety management system from $1^{\text {st }}$ October, 2012

\subsubsection{Vision \& Mission of the Organization}

Vision: "By consistently delivering the ingredients of success for the most exciting food. Health and Fragrance solutions, we will be the partner of choice to our clients worldwide."

Mission:

Growth: Grow smart, grow fast, and grow together.

Innovation: Operational excellence powered by innovation.

Customer Service: Cultivate customers, care more.

Enhance Value: For all stakeholders.

Making it a great place to work: Winning people through collaboration.

\subsection{Relevance of The Study}

Employee or labour welfare is an inclusive term of various services, benefits and facilities offered to employees by the employers. In order to retain and maintain to serve the organisation better the employees have to be trained and remunerated through various fringe benefits the employer makes the life worth living for employees, the welfare amenities are 


\section{ELK ASIA PACIFIC JOURNAL OF HUMAN RESOURCE MANAGEMENT AND ORGANISATIONAL BEHAVIOUR}

ISSN 2394-0409; DOI: 10.16962/EAPJHRMOB/issn.2394-0409; Volume 2 Issue 1 (2015)

extended its normal and economic rewards available to employees as per the legal provisions. "Labour welfare which improves the health, safety and general well-being of the industrial efficacy of the workers beyond the minimum standard laid down by the legislation

\section{Literature Review}

Rashmi Jain (2012): Working conditions vary greatly. Production workers, including frontline managers and supervisors, spend most of their shift on or near the production floor. Some factories are noisy and can have airborne fibers and odour. Work-related injuries and illnesses in textile product mills averaged 5.5 per 100 full-time workers, and in apparel manufacturing, the rate was 3.6 per 100 full-time workers.

Walton (1973): Stated that the quality of work life is a phrase that contains vast meaning. It is not merely the limiting working hours in a week, or labour law that protects child labour and equitable pay, but also the inclusion of the needs and wishes of the employees for a better life of the people within the organization.

This article assesses the impact of unions on management practices to reduce labour costs, implement highperformance work systems, and make employee welfare provisions. Relative to non-union workplaces, those with unions are found to have practices which are consistent with 'mutual gains' outcomes.

Sumathi Reddy (2006): Employee health and wellness is a key concern for employers and employees alike. Intense competition, tendency for a more materialistic life and intensification of work due to modern production and processing technology are some of the factors contributing towards an imbalanced life style. Unless conscious measures are taken relating to health and wellness, it will lead to loss of productivity and working days and loss of valuable talent

Aaker (1991) established brand is regarded as a critical means for differentiating between products and creating competitive advantage for organizations. Likewise, employer branding has become a new approach in order to gain an edge in the competitive world.

Ambler and Barrow (1996) defined employer branding as the package of functional, economic, and psychological 


\section{ELK ASIA PACIFIC JOURNAL OF HUMAN RESOURCE MANAGEMENT AND \\ ORGANISATIONAL BEHAVIOUR}

ISSN 2394-0409; DOI: 10.16962/EAPJHRMOB/issn.2394-0409; Volume 2 Issue 1 (2015)

benefits provided by employment, and identified with the employing company.

Backhaus and Tikoo, 2004: Employer branding is a relatively new approach towards recruiting and retaining the best possible human talent within an employment environment that is becoming increasingly competitive.

Minchington, 2010: The art and science of employer branding is, therefore, concerned with the attraction, engagement, and retention of initiatives targeted at enhancing a company's employer brand.

\section{Need of The Study}

Employee welfare is a word which includes various services, benefits and facilities offered to employees by the employers. The welfare measures need not be monetary but in any kind/forms. This includes items such as allowances, housing, transportation, medical insurance and food. Employee welfare also includes monitoring of working conditions, creation of industrial harmony through infrastructure for health, industrial relations and insurance against disease, accident and unemployment for the workers and their families. Such generous benefits will create the organizational branding and makes life worth living for the employees

\section{Objectives of The Study}

$\circ$ To study the different welfare facilities provided to the employees of Synthite Industries Ltd.

○ To understand the relationship between Welfare activities and Organizational Branding.

○ To know whether the employee are satisfied with the welfare facilities provided by the company.

\section{Research Methodology}

Research is defined as a "scientific and systematic search for pertinent information on a specific topic". The purpose of research is to discover answer to questions through the application of scientific procedures. The main aim of research is to find out the truth which is hidden and which has been discovered as yet. The methodology adopted for the study is descriptive based research. Mainly the primary Data will be collected through questionnaires and also certain amount of secondary data will be collected from websites and other various sources. Appropriate statistical tool will be adopted to analyse the data. 


\section{ELK ASIA PACIFIC JOURNAL OF HUMAN RESOURCE MANAGEMENT AND \\ ORGANISATIONAL BEHAVIOUR}

ISSN 2394-0409; DOI: 10.16962/EAPJHRMOB/issn.2394-0409; Volume 2 Issue 1 (2015)

Study population: Employees of

Synthite chemical industry limited

Sample Size: 50 employees. Have been chosen from the division of various position and designation as respondents for the questionnaire.

\section{Types of Data:}

Primary Data - Collected for the first time. Primary Data is collected through structured surveys with the use of a questionnaire.

Secondary Data - Those which have already been collected and analysed by someone else. Secondary data will be collected from websites, Journals, thesis, books and other various sources.

\subsection{Tool For Data Collection} (Research Instruments)

\section{The Questionnaire:}

Structured surveys employ the use of a questionnaire. A questionnaire consists of a set of questions presented to a respondent for answers. The respondents read the questions, interpret what is expected and then write down the answers themselves. It is called an Interview Schedule when the researcher asks the questions (and if necessary, explain them) and record the respondent's reply on the interview schedule. Because there are many ways to ask questions, the questionnaire is very flexible. Questionnaire will be developed and tested carefully before being used on a large scale.

\section{Data Analysis and Interpretation}

1. The company provide many welfare facilities Table showing the Welfare facilities provided by the organisation

(Refer Table 1 Here)

Interpretation: The above Table No.: 1, represent that, $80 \%$ of the employees are aware of the welfare facilities in their organisation.

2. How you are communicated about welfare facilities provided by the organisation

Graph showing communication of employee welfare facilities

(Refer Figure 1 Here)

Interpretation: Employees of the organisation are communicated $36 \%$ by circulars about welfare facilities, $28 \%$ through meetings, $28 \%$ through noticeboards, and $8 \%$ by circulars. It 


\section{ELK ASIA PACIFIC JOURNAL OF HUMAN RESOURCE MANAGEMENT AND \\ ORGANISATIONAL BEHAVIOUR}

ISSN 2394-0409; DOI: 10.16962/EAPJHRMOB/issn.2394-0409; Volume 2 Issue 1 (2015)

means employees are provided with the welfare facilities information.

3. Rank the facilities that benefits you the most

Table showing that facilities that benefits most to the employees

(Refer Table 2 Here)

Interpretation: The company is providing many facilities to the employees but the employees are most benefited from the medical facilities that is $58 \%, 22 \%$ of the employees are benefited from first aid facilities, $12 \%$ of the employees are benefited from canteen facilities, $6 \%$ of the employees are benefited from education facilities and $2 \%$ of the employees are benefited from cultural facilities.

4. According to your perception please rate the following benefits of employee welfare

Table showing that perception of employees towards benefits of employee welfare

(Refer Table 3 Here)

(Refer Figure 2 Here)

Interpretation: According to the perception of the employees towards employee welfare benefits the top ranking is given that it creates efficiency towards work and least rank is given to increase standard of living and the second rank is given to that it help to promote healthy industrial relation followed by loyalty towards work.

5. Are you satisfied with the welfare facilities provided by your company?

Satisfaction with welfare facilities provided by the company

(Refer Table 4 Here)

Interpretation: The above Table No.: 4 shows that, the major part of the employees working in the industries are satisfied that is $74 \%$, $4 \%$ of the employees are highly satisfied and $22 \%$ of the employees are not satisfied with the welfare facilities provided by the organisation.

6. I am proud being an employee in Synthite Company limited?

Table showing that employee being proud to be an Synthite employee

(Refer Table 5 Here)

(Refer Figure 3 Here)

Interpretation: Employees of the company possesses high employee 


\section{ELK ASIA PACIFIC JOURNAL OF HUMAN RESOURCE MANAGEMENT AND \\ ORGANISATIONAL BEHAVIOUR}

ISSN 2394-0409; DOI: 10.16962/EAPJHRMOB/issn.2394-0409; Volume 2 Issue 1 (2015)

morale towards industry, $50 \%$ of the employees agree, $26 \%$ of the employees are strongly agree and proud to be an employee of the organisation.

7. Does the employee productivity has increased due to the welfare facilities provided?

Table showing that productivity of the employees

(Refer Table 6 Here)

Interpretation According to the supervisors $72 \%$ of the employees are productive other $4 \%$ are highly productive and $24 \%$ of the employees are not productive.

\section{Findings}

It has been found $80 \%$ of the employees are aware of the welfare facilities provided in the organisation, Employees are communicated about the welfare facilities by circulars meetings and noticeboards. And $48 \%$ of the employees are working in the range of $46-48$ hours, $42 \%$ of the employees are satisfied by the duration of the time to rest between working hours. Company provides canteen facility to the employees, $80 \%$ of the employees are agree that the company premises are clean. It also provides first aid box, medical facilities and ambulance facilities to all employees and also provides precautions in case of fire accidents. $76 \%$ of the respondents are provided with goggles, $74 \%$ of the respondents are provided with Gloves, $84 \%$ of the respondents are provided with Helmet, $94 \%$ of the respondents are provided with shoes and $100 \%$ of the respondents are provided with uniforms. $38 \%$ of employees perception about employee welfare facilities is it will create efficiency towards work \& $74 \%$ of the employees are satisfied by the welfare facilities provided by the company. $50 \%$ of the employees feel proud to work in Synthite, and $72 \%$ of the employees agree that employee welfare facilities leads to employee's well-being. The company will provide leave to employees on demand when required.

\section{Suggestions}

- Organisation can provide quarter's facilities to employees: As per my knowledge, Synthite industry is providing bachelor quarters facilities to its employee but the organisation 


\section{ELK ASIA PACIFIC JOURNAL OF HUMAN RESOURCE MANAGEMENT AND \\ ORGANISATIONAL BEHAVIOUR}

ISSN 2394-0409; DOI: 10.16962/EAPJHRMOB/issn.2394-0409; Volume 2 Issue 1 (2015)

can provided family quarters facilities to its employees also as they are requesting for the same. And it shows the organisation concern towards the employees

- Organisation can provide transportation facility to all the employees: The organisation can provide bus facility to the employees who travel from Harihar and Davangere which helps the employee to get with in time to their work which will boost their morale.

- Change rooms facilities can be provided to the employees in the organisation: Change room facilities can be provided to the female employees and to the employees who are working in production and engineering department where they use safety equipment's when they are working. Secure and concern towards employees

- Organisation can conduct open house program to their views regarding welfare facilities: Open house or door open program is an event held by the company where it's all the employees' can share their views regarding the organisation and it is a special event organised by the managers to all the employees of the organisation in a particular day and time to collect their views completely unbiased without any hierarchal issues. It is like treating all the employees equally and providing the common platform to share their problems and views which might increase the employee loyalty.

- Recreational activities can be conducted monthly to all the employees like sports (indoor and outdoor games), and cultural events, festivals (national and regional), family get together and can do birthday celebration of the employees. And recreational facilities can motivate the employees and it helps the employee to refresh their mind from work pressures

- Recognition program should be conducted which helps in motivating the employee. To motivate the employee's organisation can provide recognition like awards and rewards, certificate, badges and hall of fame to the best performer employee's and it helps to motivate the employee and increase the productivity

\section{Limitations Of The Study}




\section{ELK ASIA PACIFIC JOURNAL OF HUMAN RESOURCE MANAGEMENT AND \\ ORGANISATIONAL BEHAVIOUR}

ISSN 2394-0409; DOI: 10.16962/EAPJHRMOB/issn.2394-0409; Volume 2 Issue 1 (2015)

i. All the employees could not be contacted due to their busy work schedule.

ii. The study is restricted to welfare department only, to be focused and not divert my study into other problems related to training, performance appraisal etc.

iii. The study is restricted to 50 employees due to time constraint.

iv. Analysis of the data collected has been done based on the assumption that the information provided by the respondents is genuine

\section{Conclusion}

The welfare facilities provided by the Synthite Industries is according to the standards. $80 \%$ of the employees are aware of the facilities provided by the company. Almost all the employees are availing of canteen facility, First aid facility, medical facility and ambulance facility. Safety equipment's are provided to the employees involved in risky task. Many of the employees felt that their working premises are clean. Loan facility is provided to the employees like education loan personal loan medical loan and housing loan.

Lastly, it can be concluded that, company provides many welfare facilities which the employee like and in turn this may help to increase employee productivity, morale and their commitment towards the company and it leads to creating a positive attitude towards the organization and creates organizational branding.

\section{References}

\section{Journal Papers:}

[1] Aiman-Smith, L., Bauer, T.N., and Cable, D.M. (2001). "Are you attracted? Do you intend to pursue? A recruiting policy capturing study", Journal of Business and Psychology, 16(2), 219-237.

[2] Backhaus, K. B. and Tikoo, S. (2004): "Conceptualizing and researching employer branding", Career Development International, Vol. 9, No. 5, pp. 501-517

[3] Ehrhart, K.H., and Ziegert, J.C. (2005), "Why are individuals attracted to organizations?" Journal of Management, 31, 901-919

[4] Minchington B (2011), “Employer Branding Without Borders: A Pathway for Corporate Success"

[5] Rashmi Jain: Exploring the working condition and facilities for worker of apparel industry of Jaipur Posted: Apr 08,2012 


\section{ELK ASIA PACIFIC JOURNAL OF HUMAN RESOURCE MANAGEMENT AND \\ ORGANISATIONAL BEHAVIOUR}

ISSN 2394-0409; DOI: 10.16962/EAPJHRMOB/issn.2394-0409; Volume 2 Issue 1 (2015)

[6] Rynes, S.L. en Barber, A.E. (1989), "Applicant Attraction Strategies: an Organizational Perspective", The Academy of Management Review, 15(2), 286-310.

[7] Walton (1973) Quality of work life. Slogan management review, 15(1):1112.

[8] Sumathi Reddy, (2006) - HRM review- employee health and wellness 2006 Perspectives and cases Icfai publication Hyderabad

[9] Wilden, R, Gudergan, S \& Lings, I 2010, 'Employer branding: strategic implications for staff recruitment', Journal of Marketing Management, vol. 26, no. 1-2, pp. 56-73.

[10] Nupur Bhati, (2014) EMPLOYER BRANDING: AN OVERVIEW, International Journal of Marketing, Financial Services \& Management Research ISSN 2277-3622 IJMFSMR, Vol.3 (6), JUNE (2014), PP. 160-169 Online available at indianresearchjournals.com

\section{Books:}

[11] Aaker, D (1991), Managing Brand Equity, Free Press, New York.

[12] Barrow, S., and Mosley, R. (2005), 'The Employer Brand: Bringing the Best of Brand Management to People at Work', Chichester: Wiley.

[13] Cassidy C. and Kreitner R.(2010), Supervision: setting people up for success, SouthWestern Cengage Learning, Mason, USA

[14] HRM review- employee health and wellness - Sumathi Reddy 2006.

[15] BD Singh, 1998 "Industrial relation", Edition $5^{\text {th }}$, publication: Excel Books, New Delhi.

[16] Industrial Relations Journal, Vol. 36, No. 5, pp. 348-366, September 2005.

[17] Subba Rao, 1996 , “ Human resource management and industrial relation", $7^{\text {th }}$ edition (Revised edition 2005), Himalaya publishing house, New Delhi 


\section{ELK ASIA PACIFIC JOURNAL OF HUMAN RESOURCE MANAGEMENT AND ORGANISATIONAL BEHAVIOUR}

ISSN 2394-0409; DOI: 10.16962/EAPJHRMOB/issn.2394-0409; Volume 2 Issue 1 (2015)

\section{List of Figures:}

[1] Figure No.: 1 Graph showing communication of employee welfare facilities

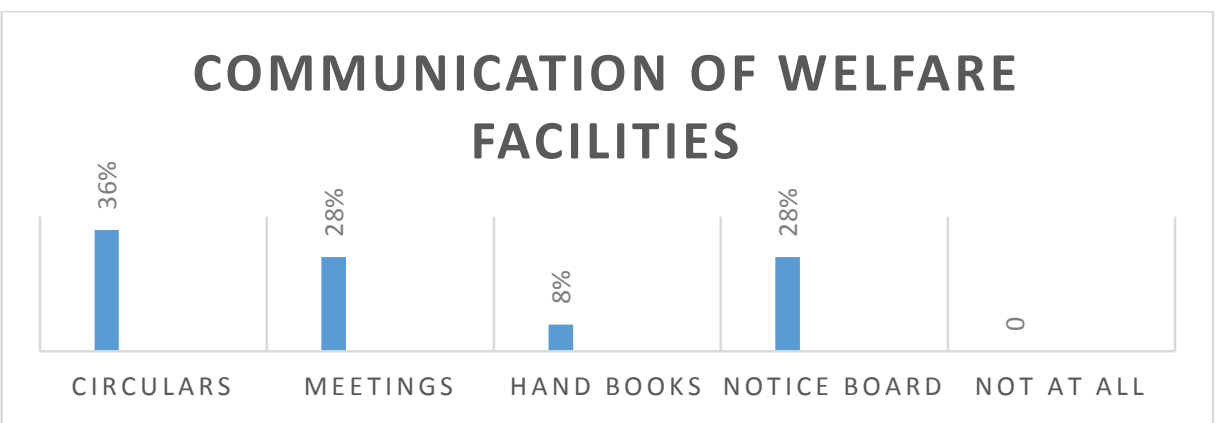

[2] Figure No.: 2 Graph showing benefits of employee welfare

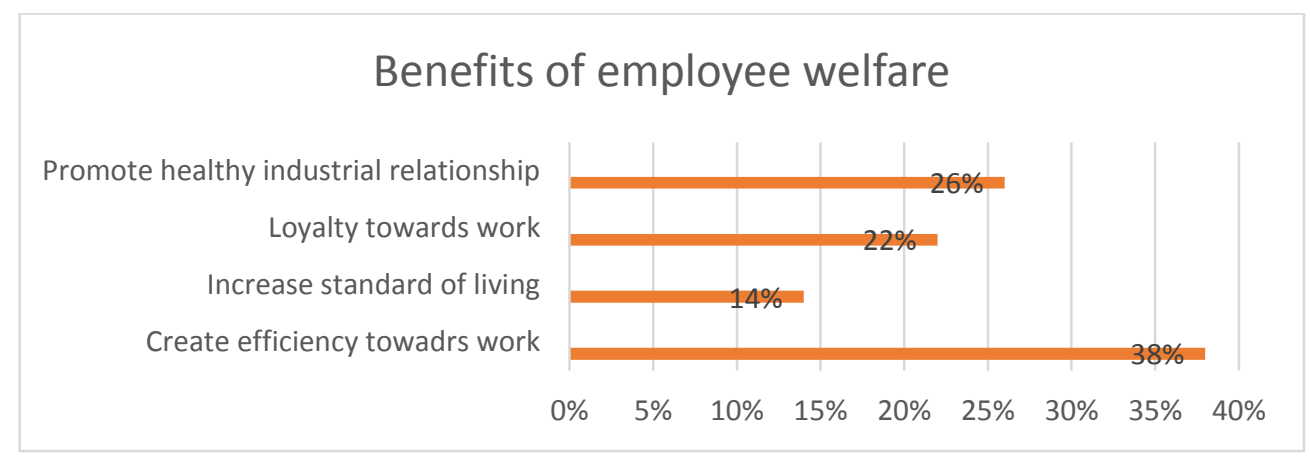

[3] Figure No.: 3 Graph showing proud to be an Synthite employee

\section{Proud to be synthite employee}

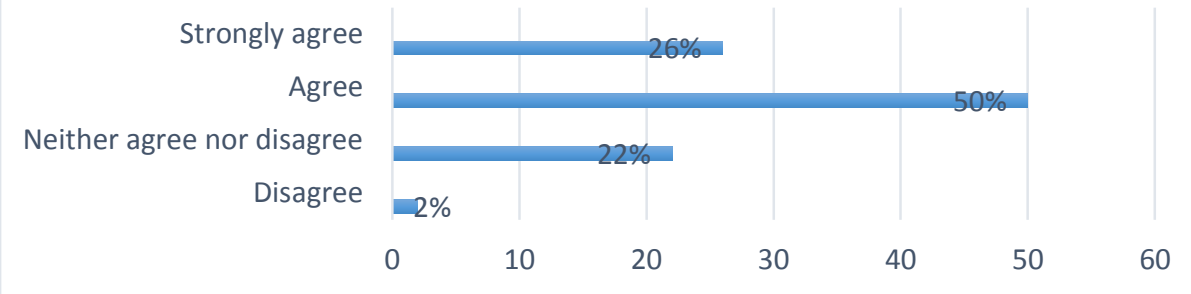




\section{ELK ASIA PACIFIC JOURNAL OF HUMAN RESOURCE MANAGEMENT AND ORGANISATIONAL BEHAVIOUR}

ISSN 2394-0409; DOI: 10.16962/EAPJHRMOB/issn.2394-0409; Volume 2 Issue 1 (2015)

\section{List of Tables:}

[1] Table No.: 1 Table showing the Welfare facilities provided by the organisation

\begin{tabular}{|c|c|c|}
\hline Response & Frequency & Percent \\
\hline Agree & 40 & $80 \%$ \\
\hline Disagree & 10 & $20 \%$ \\
\hline Total & 50 & 100 \\
\hline
\end{tabular}

[2] Table No.: 2 Table showing that facilities that benefits most to the employees

\begin{tabular}{|l|l|l|}
\hline \multicolumn{1}{|c|}{ Response } & Frequency & Percent \\
\hline Medical Facilities & 29 & $58 \%$ \\
\hline Canteen Facilities & 6 & $12 \%$ \\
\hline Cultural Facilities & 1 & $2 \%$ \\
\hline Education facilities & 3 & $6 \%$ \\
\hline First aid Facilities & 11 & $22 \%$ \\
\hline \multicolumn{1}{|c|}{ Total } & 50 & $100 \%$ \\
\hline
\end{tabular}

[3] Table No.: 3 Table showing that perception of employees towards benefits of employee welfare

\begin{tabular}{|l|l|l|}
\hline \multicolumn{1}{|c|}{ Response } & Frequency & Percent \\
\hline Create efficiency towards work & 19 & $38 \%$ \\
\hline Increase standard of living & 7 & $14 \%$ \\
\hline Loyalty towards work & 11 & $22 \%$ \\
\hline Promote healthy industrial relationship & 13 & $26 \%$ \\
\hline \multicolumn{1}{|c|}{ Total } & 50 & $100 \%$ \\
\hline
\end{tabular}

[4] Table No.: 4 Table showing Satisfaction with welfare facilities provided by the company

\begin{tabular}{|c|c|c|}
\hline Response & Frequency & Percent \\
\hline Dissatisfied & 11 & $22 \%$ \\
\hline Satisfied & 37 & $74 \%$ \\
\hline Highly satisfied & 2 & $4 \%$ \\
\hline Total & 50 & $100 \%$ \\
\hline
\end{tabular}




\section{ELK ASIA PACIFIC JOURNAL OF HUMAN RESOURCE MANAGEMENT AND ORGANISATIONAL BEHAVIOUR}

ISSN 2394-0409; DOI: 10.16962/EAPJHRMOB/issn.2394-0409; Volume 2 Issue 1 (2015)

[5] Table No.: 5 Table showing that employee being proud to be an Synthite employee

\begin{tabular}{|c|c|c|}
\hline Response & Frequency & Percent \\
\hline Disagree & 1 & $2 \%$ \\
\hline Neither agree nor disagree & 11 & $22 \%$ \\
\hline Agree & 25 & $50 \%$ \\
\hline Strongly agree & 13 & $26 \%$ \\
\hline Total & 50 & 100 \\
\hline
\end{tabular}

[6] Table No.: 6 Table showing that productivity of the employees

\begin{tabular}{|l|c|c|}
\hline \multicolumn{1}{|c|}{ Response } & Frequency & Percent \\
\hline Not productive & 12 & $24 \%$ \\
\hline Productive & 36 & $72 \%$ \\
\hline Highly productive & 2 & $4 \%$ \\
\hline Total & 50 & $100 \%$ \\
\hline
\end{tabular}

